\title{
12. Conclusion: empirical insights on the politics of knowledge production and its transfer into policy and practice
}

Briony Jones and Ulrike Lühe

\section{INTRODUCTION}

It's right to turn the page but first you have to read it. You have to understand it. You first have to acknowledge it and then you turn the page. ${ }^{1}$

This oft-cited quote from Alex Boraine, former Vice-Chairperson of the South African Truth and Reconciliation Commission, captures the idea that we cannot address the past if we do not know what happened, connecting knowledge to a capacity to act (Grundmann and Stehr, 2012: 16-17). In this sense it also raises a series of assumptions and concerns which are central to this book. First, the capacity to read requires a literacy. This ability to read may be held by some and not others. Second, reading is not only a technical skill, it is also an ability to interpret, to find meaning, and to reflect on what has been read. Third, reading words on a page cannot capture the volume or tone with which they would be spoken by others, as they are brought to life in real experiences. Fourth, there is always a writer and a reader, and we need to know who wrote the words, under what conditions, and for whom they were intended. This politics of knowledge, of who can speak and write, of who is heard and read, and of how knowledge is interpreted for action, is fundamental to a field such as transitional justice which operates on the assumption that the more we know the better we will be able to seek justice or the more able we are to achieve peace (Kritz, 2009; Forsythe, 2011).

This search for better evidence and a trust in the assumption that better evidence will indeed lead to better policies cuts across the different knowledge communities that shape transitional justice. Van der Merwe and Brinton Lykes (2018: 381) have described how 'academics engage each other on a tumultuous battle ground of ideas and empirical claims [...] to build some solid ground for empirical engagement', while Palmer and colleagues have described transitional justice researchers as 'agents of change' (Palmer et al., 
2015: 178; Robins and Wilson, 2015). Practitioner and advocacy organizations such as the International Center for Transitional Justice (ICTJ) or the South African Institute for Justice and Reconciliation also frame 'research as a tool for action' (Ancelovici and Jenson, 2013: 301). On its website the ICTJ, for example, states that its research not only 'aims to bolster global knowledge of the successes and failures in the field, promote innovation, and inform best practice', ${ }^{2}$ but it also undertakes to do research that is 'policy friendly, and at the same time normatively rich, so as to contribute to giving content to the notion of transitional justice that ICTJ promotes' ${ }^{3}$ It believes that its 'research products have had significant impact on both national and international policy'. ${ }^{4}$ These examples are illustrative of the claims being made by both academics and practitioners regarding the importance of knowledge, produced by academics as well as NGOs and other stakeholders, in shaping transitional justice policy. Furthermore, both law and politics - the academic fields from which transitional justice emerged - are 'oriented or easily adapted to policy and prescription' (Fletcher and Weinstein, 2015: 189).

As referred to throughout this book there is a body of work which describes and analyses this politics of knowledge. Our book contributes to this work in two key ways. First, we show how this politics of knowledge determines the basis on which many policies are made as well as the ways they are implemented. Second, we connect this politics of knowledge to the research-policy-practice interface. This speaks to the boundaries and claims of the field of transitional justice, but also more broadly to peace and conflict studies as well as to international relations scholars who are interested in how what comes to count as 'knowledge' shapes the claims about the ways we act in and on the world. In this concluding chapter we bring these threads together and reflect on the contributions of the individual chapters and on the collection as a whole. We see some general themes emerging from the chapters which we discuss in turn before returning to our contributions to scholarship: the processes and actors that produce knowledge; norms, interpretations and imbalances of power which shape and are shaped by the politics of knowledge; and the research-policy-practice nexus which forms a particular part of transitional justice's politics of knowledge.

\section{PRODUCING KNOWLEDGE: PROCESS AND ACTORS}

We can see clearly in each of the chapters of this book the political nature of knowledge production processes. ${ }^{5}$ This is not to deny their technical, skills-based or procedural elements. Rather, we argue that just because producing knowledge for transitional justice requires certain skills, resources and planning, it does not mean that the use of these skills, or the identification of resources, is not political. As Halistoprak observes in his chapter, 'the phrase 
"knowledge production" itself signals a methodological departure from the positivist school, which assumes reality is out there waiting to be explored through scientific methods'. Our starting point for this book was in this sense a constructivist one, not taking for granted any stable or objective category that could be referred to as 'knowledge'. What we see in the chapters is an emergence of varied and subjective knowledges, which come to be known as such, and at times elevated to the level of authoritative knowledge, i.e. expertise, by virtue of the contexts in which processes, actors and interpretations are afforded legitimacy. Knowledge is captured in each of our chapters as contestable and contested, and in this section we reflect particularly on the conditions of its production.

One of the first observations is the sheer variety of types of knowledge production processes, forms of knowledge and, indeed, knowledge dissemination. We have knowledge produced for specific transitional justice interventions: the truth commissions in Wouters's chapter, the internationally led mediation of South Sudan's peace process in Logo's chapter, the African Union (AU) policy-making process in Lühe's chapter, and the social cohesion programmes in Côte d'Ivoire in N'Da and Fokou's chapter. This knowledge - aimed at and tailored to very specific policy processes and outcomes - comprises expert statements, mechanism reports, monitoring and evaluation reports, and policy documents. However, there are also the processes and politics of knowledge production that surround these transitional justice processes by shaping the discursive environments in which they take place. Bigirimana has illustrated this by highlighting the discourses of ethnicity, decisions over the labelling of conflicts as genocide, and the availability of international reports that use one or the other terminology, all of which shape the narrative and discursive environment in which not only the researcher has to position him- or herself, but in which decisions about transitional justice are also being taken. In his chapter we also see starkly the way in which narratives of the past are contested through epistemic as well as physical violence, and that this is as much a process which takes place within the academy as it is a process which individual researchers have to navigate.

We furthermore learn that in order for these processes to produce something which is seen as 'knowledge' it needs to be legible to certain audiences, conferred with credibility and have a certain mobility. We also learn that there is continual contestation over how the knowledge production process should unfold, whether this is in formal consultations with experts in Lühe's chapter, workshops with the wider population in Njeru and Masiya's chapter on Zimbabwe or informal bargaining by national political elites in Lambourne's chapter on Burundi. The ways of sharing and communicating this knowledge are complicated by language - spoken, written and implicit. Njeru and Masiya, as well as Lambourne, highlight problems with transitional justice training 
of local populations in non-local languages, as well as using technical terms which are born of the internationalized non-governmental world of transitional justice civil society. The modes of communication and dissemination say a lot about who can speak, and who should listen.

This idea connects to and expands on the emerging literature on the nature of the expert and their expertise in IR and peacebuilding (e.g. Berling and Bueger, 2016; Littoz-Monnet, 2017a; Leander and Wæver, 2019). The chapters by both Wouters and Lühe explicitly focus on the figure of the expert who is brought into transitional justice processes in order to produce knowledge, validate knowledge and/or confer credibility on knowledge production and policy-making processes. The patterns of expertise are not always easily readable, and detailed analyses of specific cases demonstrate that experts are considered to be experts due to nuances in context and the requirements of specific processes. Wouters demonstrates that differing ideals of objectivity, as well as needs of different truth commissions, can explain the varied epistemic profiles of commissioners - some confer authority, some bring skills and others indirectly represent parts of the population. What is important, she argues, is that 'policymakers and commissioners should be aware of how their own backgrounds might influence the results of their work'. In her work on experts in the AU Transitional Justice Policy process Lühe describes an assemblage of expertise, brought together in particular places and at particular times and in which 'expert status for, and in, this process was derived equally from education, practical experience, networks, and international and regional acknowledgement of expert status'. Both of these chapters highlight the concrete ways in which such dynamic and varied assemblages of expertise shape policy outcomes, in terms of the content of reports or statements, selections and constructions of narratives, or how they are received by audiences. In other chapters we see less directly, but also importantly, the working of expertise and the emergence of experts. The transitional justice training in Njeru and Masiya's chapter conferred expert status on the trainers fluent in internationalized transitional justice language, while at the same time essentializing the local communities and missing an opportunity to engage them as credible repositories of justice knowledge.

A key assumption underlies these dynamics of expertise: that the beneficiary population is ultimately malleable, able and willing to sing to the transitional justice hymn sheet if only given the 'correct' knowledge - this acknowledges neither the multitude of discourses and preferences in interpreting certain events that exist within a specific context, as we have seen in Bigirimana's chapter, nor does it account for the fact that regional connections and elite preferences can very well overwrite the preferences of an affected population, as we have seen in Logo's contribution. In this logic, knowledge production is furthermore simplified into a transaction, a movement of the 
object of knowledge from one party, who owns the knowledge, to another party, who does not - which in turn is based on assumptions of universality and transferability. The earliest works that came to shape the field of transitional justice already forward this idea. Kritz (1995: xix) for example highlights 'the extent to which the Central and Eastern Europeans and former Soviets who were just emerging from communist rule could learn any useful lessons from the Latin American transitions of the previous decade'. Similarly the Project for Justice in Times of Transition which took place around and shaped some of the first transitional justice processes, 'brought together almost 40 individuals who are directly involved at the policy-making level' with the aim of 'seeking lessons from the past and present experiences of countries which have already attempted to address these issues' (Albon, 1995: 43). Fletcher and Weinstein's (2015: 190) analysis of early transitional justice scholarship provides further proof in finding that 'most of the influential articles were analytic papers and theory-building ones, suggesting that consumers of transitional justice scholarship prioritized work that offered lessons and models that could be applied across particular cases and contexts'. Despite the 'vibrant intellectual production' of academic transitional justice knowledge (ibid.: 177), there remains a strong focus on principled research that is at least partially driven by individual investment in specific ideas but also an emphasis on 'templatization or standardization of best practices [that] defines TJ as an organizational field' (Subotić, 2012: 121). The combination of normative universalist rights discourses, the focus on transferable models and a presumption of apoliticality all lead to transitional justice claiming 'universal range and, paradoxically, strong political volunteerism' (Lefranc and Vairel, 2013: 236) in which 'learning processes' become a key mechanism for policy-making (Andre du Toit, referenced in Vanantwerpen, 2009: 111). Several forms of these learning processes, be it through consultation, training or report writing and documentation, have been outlined in various chapters.

The power dynamics inherent in these ideas of transferability and universality are clear in Njeru and Masiya's chapter: it 'illustrates a key assumption of the Forum: that sustained discussions would naturally follow among ordinary Zimbabweans across the country and that people-driven transitional justice options and mechanisms would emerge, forcing the government to act'. Furthermore, 'the Forum commoditized transitional justice and mistakenly overestimated the Zimbabwean communities' willingness to play their role in participating as victims of political violence'. Expectations around the roles to be played by local communities, victims' groups or beneficiaries can also be seen in N'Da and Fokou's chapter on Côte d'Ivoire:

In the space of three months and even before his investiture ceremony as President of the Republic, Alassane Ouattara had already developed a roadmap to lead the 
post-war process. What is noteworthy is that neither national consultations, nor public debates, open to a wide range of social actors, such as media, victims or opposition parties, were conducted. This lack of inclusion and participation in determining the process of peace-seeking and national reconciliation is surprising considering the context of social division in the country.

This contradicts the value that is assigned to participation and participatory processes in transitional justice literature and practice (Vinck and Pham, 2008; Triponel and Pearson, 2010; Robins and Wilson, 2015) and reinforces the view that participation of both victims and the public is often symbolic rather than substantive, as has been shown to be the case in the negotiations for the Rome Statute (Glasius, 2002) and many other policy platforms. Looking at the two chapters by Njeru and Masiya and by N'Da and Fokou together, as well as the other chapters in the book, indicates that we cannot assume that a given knowledge production process has a certain politics of knowledge. Consultations are not necessarily consultative, centralized state action may be contested by active civil society, and control over knowledge production is deeply embedded in the history of places and institutions as well as the current political constellations. Lambourne's chapter on Burundi looks at a knowledge tug of war between the UN, the national government and the population, leading to negotiations over justice which have as much to do with political jostling as they have to do with justice-seeking, with 'profound influence on the mechanisms and programs that have been pursued and the impact these have had'.

The cases of Burundi, Zimbabwe and South Sudan also point to the politics of time and timing in the area of knowledge production and dissemination. In South Sudan's case (Logo), important knowledge, for example in the form of reports of commissions of inquiry, is being withheld until they become ineffective because decisions that could have been affected by the reports' contents have already been taken. In the case of Zimbabwe (Njeru and Masiya) and Burundi (Lambourne), consultations with affected people and the general population are being held, albeit after the minds of UN agencies and local actors have been made up with regard to the nature of a transitional justice process. While in Zimbabwe the consultations resemble trainings more than open discussions designed to elicit the views of the population, a survey in Burundi only 'asked about specific aspects of each of the four key pillars predefined as constituting a truth and reconciliation commission in order to seek the truth, and a special tribunal to achieve prosecutions, along with reparations and institutional reform'. Timing and sequencing are then key not only in the transitional justice process itself, but also in the process of taking decisions about its design. The second chapter on Burundi, by Bigirimana, highlights another aspect in the politics of time and timing with regards to transitional justice knowledge production, by pointing us to the differences between the 
ethnic and political communities inside Burundi and in the diaspora in terms of how they remember the same acts of violence differently, and which ones they chose to remember.

Across the chapters we have also mapped knowledge producers and experts beyond those most frequently referred to as shaping the transitional justice agenda - international NGOs such as the ICTJ or Human Rights Watch, or the UN (Jamar, 2014; Zvobgo, 2020), as well as 'elite and middle ground level' officials and 'professionals from outside the country where the conflict is happening' (Mourlon, 2016: 3) - to draw attention towards 'local' civil society, media and film-makers, researchers, and regional actors and their interaction with global, regional and local discursive frameworks. We have chapters on the AU (Lühe), on the Intergovernmental Authority on Development (Logo), on commissioners in truth commissions (Wouters), on civil society programmes in Zimbabwe (Njeru and Masiya) and Côte d'Ivoire (N'Da and Fokou), and on the internal dynamics of an international research partnership (Jones et al.). An even more complex actor landscape is presented by Bigirimana who shows the overlapping and contradictory roles of international commissions of inquiry, the diaspora, media actors, documentary makers, local elites, academics and international NGOs in shaping the contentious, complex and contradictory narrative landscape about the past in Burundi.

Lastly, while the book's own process of knowledge production was a delicate balancing act between editorial oversight and diversity of voice, it is an acknowledgement of opportunity, which the politics of knowledge theme offers, to reflect on our own processes of knowledge production as well as to engage in a dialogue with the knowledge of actors who are frequently marginalized. According to Colvin (2008: 424), the problem for transitional justice vis-à-vis the local context is not one of a lack of knowledge but rather a 'failed ethical relationship to the other'. This is a useful reminder that knowledge production matters, that we do need to 'read the page in order to turn it', but also that the conditions of the production of this knowledge, and the ethics that it implies, are even more important and are indeed too often overlooked in a rush to generate data and to make claims.

\section{POLITICS OF KNOWLEDGE: NORMS, INTERPRETATIONS AND (IM)BALANCES OF POWER}

The politics of knowledge for justice and peace refers of course to the processes of knowledge production discussed above, but also to the relationships of power which underpin knowledge norms, knowledge interpretations and imbalances between actors jostling in an uneven knowledge landscape. This brings in an element of ethics, for even in the fields of transitional justice and peacebuilding, with their focus on inequality, injustice and disempowerment, 
some knowledge is 'more equal' than other knowledge. This inequality of knowledge is connected to the knowledge production process and the assigning of expert status to some and not others, but also to the positionality of the knowledge producer (Kagoro, 2012; Ní Aoláin, 2015; Fletcher and Weinstein, 2018a; Bilgin, 2019), to the traction of certain norms and value systems - both local and global (e.g. Carr, 2010), the political functions of expertise (Boswell, 2008) and to hierarchies between different forms of knowledge (Evans, 2016). In this section we focus on these elements which emerged strongly from the chapters and reflect on what this means for the policies that are implemented in the name of justice and peace.

The first three chapters of the book - by Halistoprak, Goetschel and Jones et al. - offer reflections on the conditions of research production, the importance of the positionality of the researcher and the challenges of trying to smooth knowledge hierarchies through research partnerships. Goetschel takes the widely discussed subject of research and policy transfer in the field of peace research and encourages us to include the element of power, not only with reference to the politics of the policy process but also the understanding of the politics of peace research itself. This is something which is not often explicitly discussed but which 'influences the spectrum of thinkable and therefore available policy options. Therefore, being aware of power dimensions in research and developing possible ways of controlling for them is of eminent relevance not only for quality science but also for peacebuilding policy.' Halistoprak supports this approach, arguing that 'the field needs to continue extending its focus into these relational positionalities in knowledge production. The fruitful debate over the conditions that influence knowledge production has the potential to contribute to the field's capacity to catalyse change.' Jones et al. take as an entry point research partnerships between the Global North and Global South, and in particular that of the team which worked on the project which has given rise to this book. In a candid account of the emotions, ethics and challenges of this research partnership in practice, the authors highlight gaps in our understanding of the concrete and everyday workings of partnerships and the assumptions that underpin partnership guidance. They also point to a lack of discussion about, or theorizing of, South-South research partnerships which 'indicates a structural problem in the politics of knowledge production'.

Positionality, as we see in these chapters, is much more complex than easy assumptions about who is learning from whom or how a given individual will relate to the subject matter of the research. Bigirimana, in his chapter, grapples with his own intellectual journey as well as his encounters with formal education in the divisive context of Burundi. He explains this as a difficult and delicate balance between being led by his intellectual curiosity on the one hand and being constrained by his teachers and their narratives of the past on the other. This is an important reminder that epistemic violence occurs within 
our own life trajectories as well as between more or less powerful countries or regions. Poets (2020: 105) finds that 'the inequalities implied in the intersecting differences that make up our positionalities cannot be done away with in the field, including in collaborative and solidarity work. Such work is therefore marked by inevitable impossibilities and difficulties, and the ever-present risk of epistemic violence.' The 'Global North' and the 'Global South' researcher do not exist outside of varied and ever-changing contexts of resource access, field access, and individual emotional and intellectual journeys which come to define who we are as researchers, how we produce knowledge and how we can engage in partnerships, as discussed by Jones et al. as well as Bigirimana. They also do not exist outside of the political, discursive and structural conditions in which research is designed, funded, produced and received, as we see in the chapter by Goetschel. The politics of knowledge approach the authors take here reminds us of this and argues convincingly for a greater emphasis to be placed on understanding the politics of research itself in order to be able to understand the relevance and efficacy of the policies that it could or does shape.

The other chapters in the book continue these debates and foreground the role of Southern actors as powerful agents that shape not only the politics of knowledge production but also the processes and politics involved in translating this knowledge into policy and practice. This may seem obvious, but it is an empirically under-researched phenomenon. Njeru and Masiya in their chapter show us how the division between Northern and Southern research is often overlapped, in a transitional justice context, with that between academic and activist or grassroots knowledge. These divisions are also hierarchies, and they remind us that 'simple' or 'jargon free' language of Southern practitioners and activists is not to be confused with lack of knowledge nor a need for training. Rather, it is only the position from which this knowledge is viewed which renders it somehow less or lacking in the face of internationalized and technical transitional justice categories and labels. This preference for academic knowledge is particularly noteworthy considering the origins of transitional justice in activism and among practitioners and political elites who sought to shape the transition processes in their countries when 'there were no documents, no international experts' (Pablo de Greiff, quoted in Fletcher and Weinstein 2018a). Despite the origins in activism and practice in Latin America, Eastern Europe and South Africa, academic knowledge produced in the Global North has come to be viewed as more influential in shaping transitional justice. This authorization and legitimation of the practice of transitional justice through academic knowledge contributes to Lefranc and Vairel's interpretation that 'the concept [of transitional justice] has been less formulated to interpret a practice than to legitimate its conversion into a model by activists and concerned professionals' (2013: 250). A more cynical view 
would allow the conclusion that transitional justice emerged from 'a need by particular global interests to have experts who can claim a social scientific ability to conjure new democratic life from the corpses of authoritarian polities without giving any space to revolutionary transformation' (Harris, 2014: 216, based on Sitze, 2013).

Tensions around global norms appear in many of the chapters. They may be promoted by some actors, such as the UN, and contested by other actors, such as activists and researchers (see Lambourne's chapter), or they may make their domination felt more through their existence as discourses that limit local actors' ability to envisage transitional justice outside of these narrow normative confines (see Njeru and Masiya's chapter), or provide a narrative framework for local actors to demand accountability (see Logo's chapter). This is also evident in the chapter by N'Da and Fokou where 'newcomers, with post-conflict experience from other contexts, have positioned themselves as the main producers of discourse and knowledge on and for the Ivorian post-conflict case' while 'the vast majority of local administrators and practitioners were "novices" in these priority topics'. Logo's chapter on South Sudan, as well as Lühe's chapter on the AU, are particularly interesting. They tell us not only about the possible use of global norms as tools for local civil society and academia to try to hold leaders accountable, but they also open up the normative tension between the global norms and their contestation in African regional policy and peace processes that are seeking to create more regionally relevant institutions and at the same time to challenge and reshape the global discourses. Like scholarly work that is not taken seriously by the UN as it is perceived as 'supporting impunity for political leaders' (see Lambourne's chapter) these regional policy challenges to global norms also struggle to gain a tangible foothold in global debates.

Consultations in particular seem to have a vexed relationship with ideas of knowledge production in transitional justice. They are often promoted as mechanisms for gaining an insight into local ideas of justice and preferences, but instead of producing new insights, for example by making visible potential alternatives or highlighting alternative conceptualizations of some key concepts such as reconciliation, they merely serve to legitimate and communicate already dominant and visible knowledge. In Lambourne's chapter on Burundi for example: 'The results of the national consultations were released in a joint report by the Government of Burundi and the UN in April 2010 and were interpreted as revealing majority support for the establishment of a TRC, even though the consultations did not really provide any alternative.' Despite opposition from local civil society and proactive lobbying to the government 'the third draft of the law, which was presented to parliament in December 2012, showed that civil society lobbying had made no impact'. Njeru and Masiya found in Zimbabwe that the consultations undertaken by a local NGO were 
limited from the start. They commoditized transitional justice while presenting it as a toolbox, overestimating the willingness of Zimbabweans to "play their role in participating as victims of political violence' and mistakenly viewing them as "ready to "explode" into natural discussants of transitional justice and share their suffering'. In both chapters the consultations are framed as opportunities to present limited options and to teach the supposed beneficiaries in the language of an internationalized norm of transitional justice, rather than to learn from them of their understandings and preferences for justice and peace. International NGOs and experts continue to act as gatekeepers who not only have the ability to 'set the tone of the $\mathrm{TJ}$ [transitional justice] debate and create and recreate $\mathrm{TJ}$ templates or a menu of $\mathrm{TJ}$ options from which states may chose' (Subotić, 2012: 108) but they are also able to frame their own recommendations as international standards (Jamar, 2014). Unsurprisingly, policies which are supported by the population remain elusive in both contexts showing yet again that '[w]hile the language of transitional justice has become more locally resonant, the politics of the policy choices remain highly contentious' (van der Merwe, 2018: 213).

While the complex Global North-Global South set of relationships and imbalances is undoubtedly important, a politics of knowledge analysis which misses the in-context and South-South dynamics would be incomplete. This is particularly the case considering the fact that transitional justice has always exhibited a 'deep-rootedness in a South-South discussion that continues to this day' (Bickford, in Fletcher and Weinstein, 2018a: 240) and that many of the field's most prevalent mechanisms and concepts originated and were substantively shaped in and by the Global South (for examples see Vanantwerpen, 2009; Ancelovici and Jenson, 2013; Sitze, 2013) even if this often remains unacknowledged. In Lambourne's chapter the UN is present, but she chooses to foreground Burundian political struggles and Burundian civil society in her analysis of the 'political struggle for control over the production and dissemination of knowledge'. In N'Da and Fokou's chapter the 'usual suspects' of the international NGOs are but one part of a 'knowledge market' on social cohesion which is defined by competition between Ivoirian as well as non-Ivoirian actors, and which is dominated by the terms set by a powerful national government. In Logo's chapter on South Sudan we learn about the important regional politics as well as the stakes of various South Sudanese actors, which influence how the violence is reported, interpreted and acted upon through transitional justice policy. Bigirimana's chapter introduces us to the impact of regional conflict dynamics and entanglements on the narratives and discourses that are being used to describe the violence in Burundi. Lühe's chapter focuses on the AU and its assembling of African expertise in the formulation of its transitional justice policy framework. What we learn from these chapters is that the Global South should not only appear as the contrast 
to the Global North, but as a starting point for analyses, with the assumption that endogenous factors are just as important as exogenous ones for being able to analyse processes of justice and peace (McAuliffe, 2017). Moreover, the circulation of the international norm of transitional justice, the contestation and acceptance of different ways of knowing harm and doing justice, break down boundaries between static categories of what is 'North' and what is 'South', what is 'international' and what is 'local'.

This can be seen in the chapters by Lambourne, by Njeru and Masiya and by N'Da and Fokou where, by choice or as a consequence of structural and other factors, local actors contribute considerably to the dissemination of knowledge produced by actors originating or based in the Global North and the international norm(s) of transitional justice. The question emerges then, whether 'Southern' actors who extensively draw on and engage with ideas presumed to be produced in the 'North' are 'local' or 'international' actors? Can we separate the location of the actors from the knowledge, norms and ideas they convey, even if these ideas are at times produced elsewhere? The sense of mobility, of both knowledge and people, that permeates many of our analyses adds to the blurring between these categories. Many of those who produce knowledge or who, as experts, contribute to its dissemination, are highly mobile, both between contexts and institutions. This is evident in the chapter by Lühe, which shows us that many experts have not only engaged with different transitional justice institutions, but they have also been educated and worked in various countries and continents. But it is also evident in the very team that conducted the research for the Knowledge for Peace project of which this book is a result. With all of the project members being highly mobile, presenting at international conferences as well as more localized workshops, we may arguably be considered local and international. In the chapter by Jones et al., where the project team reflects on these questions, we see that an individual researcher is never representative of only one space or one positionality. Moreover, as we see in the chapter by Lühe, the act of labelling the 'local' or 'international' is a combination of one's standpoint and the intention of others in assigning these labels through their gaze.

\section{KNOWLEDGE FOR PEACE: FROM KNOWLEDGE TO POLICY AND THE RESEARCH-POLICY-PRACTICE NEXUS}

Our book has contributed to a deeper understanding of the politics of knowledge for peace, with contributions from researchers, practitioners and those engaged in advising on policy-making. All of these knowledge communities are considered 'generative of the field' (Fletcher and Weinstein, 2015: 192) making transitional justice both a matter of political practice and its academic 
justification (Franzki and Olarte, 2014). In bringing together the authors in this book, who are themselves academics, practitioners, consultants and advisors, it was clear that the boundaries between what counts as 'research', 'policy' or 'practice' are blurred and ever shifting, and that the politics of knowledge has a very real impact on what policies are thinkable, let alone implemented. This is more than a question of knowledge transfer between research and policy domains. It is a question of how knowledge comes to be seen as useful in context, and how this in turn is shaped by the interface and overlaps between research, policy and practice as we have outlined in the introduction to this book. The chapters by Goetschel and Halistoprak highlight that peacebuilding in general is characterized by a mission to know more in order to contribute to peacebuilding. Transitional justice is even more attuned to this research-practice-policy nexus given its origins as a 'proto-science' (Lefranc and Vairel, 2013: 236) - a field of legal and political activism responding to past violations of human rights by ousted regimes in Latin America and Eastern Europe in the 1970s through to the early 1990s which developed into a field of academic enquiry (Elster, 2013; Quinn, 2016; Zunino, 2019). It both emerged from and remains vested in international humanitarian law and universal rights discourses (Teitel, 2003a, 2003b; Arthur, 2009). Key academics in the field are often consultants to justice interventions, as we see in the chapter by Lühe on the assembling of expertise by the AU, and by Wouters on the commissioners of truth commissions. Practitioners often participate in the (re)production and dissemination of concepts and norms which determine the direction of research, as we see in the chapters by Njeru and Masiya. In each chapter we see the continual creative tensions between research, policy and practice, and how the individual authors themselves navigate their identities within and between these epistemic communities.

We see clearly in the chapters of this book that there is never just one research-policy-practice nexus. The varied analyses offer a new reading which refers neither to a simple and idealized one-way street in which knowledge, produced by scholars and practitioners, translates into policies through evidence-based policy-making, nor to the cynical opposite view in which politics, represented through agenda setting and policy-making, is exclusively driven by elitist interests and power calculations. Instead, what emerges is a complex multi-directional interaction between knowledge, policy and power that at times leans more towards the one and at other times more towards the other. This delicate balancing act is influenced by the political context and relative freedom of expression (as we read in Goetschel's chapter), by the interests of powerful key stakeholders able to withhold or reinterpret reports (as we see in Logo's chapter) and by the struggle to render dominant international discourses of justice legible in regional or national contexts (as we see in Lühe's chapter). Moreover, the motivations of actors seeking to shape 
a knowledge agenda are a mix of power-seeking, national interest, normative ideals, experience and opportunity. There is no journey from research to policy, but rather a series of tracks which intersect, wind around and overlap.

This complex picture which emerges is also a function of the analytically inadequate categories of 'research', 'policy' and 'practice'. Individual authors refer to their multiple roles in their overlapping identities as researchers as well as practitioners or policy advisors. It doesn't necessarily make sense to cleave to one specific identity, but the mobilization of one's epistemic identity will serve a purpose. The chapters by Lühe and by Wouters on the role of experts in transitional justice illustrate how identifying as a researcher or a practitioner will be useful or gain more credibility at different times and in different contexts depending on practical need as well as political mood. This deserves more attention in our analyses, by asking why knowledge produced by certain people in certain contexts is seen as 'research' and by others as 'practice' or 'policy'. Could we also consider the research we undertake, especially the more ethnographic forms, as a practice? Could we consider the practitioner dialogues and policy consultations as a form of research? There is a spectrum which runs between forms of knowledge that are embedded in theories and forms of knowledge that are in turn embedded in action. However, there is no 'pure' point on this spectrum. Halistoprak's chapter reminds us of the international relations and peace studies work which demonstrates the ways in which theory and practice are mutually constitutive: 'theory shapes the practice while practice opens the door to the reproduction of theory'. This chapter, along with that of Jones et al., highlights how the interaction between the researcher and the social and political world are indeed mutually constitutive. It is thus more pertinent to ask why some actors are considered researchers or why some forms of knowledge production are considered research. This has as much to do with some innate characteristics of the knowledge production process or knowledge form itself as it has to do with the politics of knowledge.

This touches upon the instrumentalization of knowledge, which is a recurring theme in the book. This is not just a case of how knowledge can be wielded for political purposes (Boswell, 2017; Littoz-Monnet, 2017b). The chapters also show that the identification of certain knowledge as 'research' or 'practice' or 'policy' confers greater or lesser credibility, and this may serve the agendas of different stakeholders. The peace field can be a challenging environment for critical thinking, as discussed in Goetschel's chapter as well as in other work from which we draw our insights. Bush and Duggan (2014) have written of the complex synergies between peace researchers and donor institutions, which in most cases also act as practitioner organizations, sometimes limiting access for counter-intuitive knowledge to policy-making. Contract-based research agendas and the responsibility of research teams to report to donors make it difficult to produce counter-intuitive knowledge or 
to inform policy-making. We wish to add to these debates by articulating the importance of the subjective labelling of 'research', 'policy' and 'practice'. Njeru and Masiya connect their analysis of the transitional justice programme of a local NGO in Zimbabwe with a larger discussion around the labelling of practitioners' knowledge as something qualitatively different from, and less than, research knowledge. This maps onto the Global North-South dynamic we discuss above and an uneasy distinction between the international/research/ expert knowledge and the local/practice/limited knowledge. This division is ever shifting, as we see in Lühe's chapter where expertise is labelled as 'research' or 'practice' depending on the kind of credibility sought by those leading AU policy formulation process. In Lambourne's chapter we see how a Burundian NGO was able to adapt the received 'expertise' of the UN and its four pillars of transitional justice to undertake 'practice' work which would, were it to have been conducted at a desk in a university, have been considered a research contribution to the conceptualization of justice.

The research-policy-practice nexus breaks down when we acknowledge that there is no 'research', 'policy' or 'practice' outside of the politics of knowledge which labels them as such. This leads to a series of questions which build upon but also go beyond previous work. Instead of looking at how research transfers into policy, or how research agendas are shaped by donors' or practitioners' priorities, we should ask why and in which contexts we use the labels of 'research', 'policy' and 'practice' and how this intersects with the claiming of epistemic identities by actors. This then renders visible not only the politics of knowledge, which renders certain knowledge and certain actors more credible than others, but also the factors which influence which policies are pursued in a given time and place. If we label the dialogue workshops of local NGOs as 'practice' and imbue them with a sense of particular, bounded and limited use, then it is unsurprising that we see in many of our chapters an identification of a lack of uptake of counter-intuitive or counter-narrative policies. Likewise, if we see the knowledge outputs of certain experts as research and imbue it with a sense of mobility, universality and relevance then it is unsurprising that we see in our chapters the presence of a few transitional justice experts from the Global North in local trainings and consultations. Njeru and Masiya critique the Taking Transitional Justice to the People Programme in Zimbabwe for its 'toolkit grafted from influential knowledge producers in the Global North' such as Ruti Teitel and Priscilla B. Hayner with 'no possibilities of finding spaces for African voices or culturally relevant approaches in the transitional justice debate'. But we know, from our chapters, as well as the work of many others in the field (Ní Aoláin, 2015; Fletcher and Weinstein, 2018a), that those marginalized voices are there and are equally full of insight and relevance. We also know that epistemic violence runs through the problematic Global North-South relationships in transitional justice (Fletcher and Weinstein, 
2018b). What we add is that the labelling of 'research, 'policy' and 'practice' is also part of this politics of knowledge and maps onto and reproduces these problematic imbalances of power. We also show that this has a direct impact on the kinds of policies we imagine to be feasible or credible. The politics of knowledge production, and the fact that we imbue academic knowledge with authority over practitioner knowledge, then go a long way in contributing to the current policy preferences, for example in favour of trials and truth commissions over local, non-judicial processes (Arthur, 2018; Arthur and Yakinthou, 2018). The influence of these politics also contributes towards explaining the prevalence of transitional justice as a policy approach and discourse despite the 'poor record of externally driven TJ in nontransitioning contexts' (Macdonald, 2019: 226) and its inability 'to account for its own impact' (de Greiff, 2013: 552).

\section{CONCLUSION}

The academy, the field, and the societies in which both are nested are continuations of one another, not boundaries. (Poets, 2020: 112)

This book has contributed one piece to the puzzle of a preceding body of work on the politics of knowledge in peace studies, international relations and transitional justice. These fields which seek to look outwards, to intervene in 'other' societies, and to generate change and impact in the 'real world' have a lot to grapple with in this area. Referring to academics, Bliesemann de Guevara and Kurowska (2020: 167) observe that '[we] are supposed to know before we get a grip of what there is to know, and control the process of bringing such knowledge to bear'. This insight might well be applied also to practitioners and policy-makers who cannot fail, or experiment, when peace and justice are at stake. The chapters in this book join other work by articulating the assumptions and biases with which we approach knowledge of, and intervention in, contexts of violence and injustice. They have also highlighted how this feeds into a politics of knowledge in which very often knowledge production processes serve to reiterate what is already assumed to be known - that certain policies are the best policies, that certain people want particular interventions, and that certain interventions will lead to expected outcomes. We have added an additional lens by focusing on two red threads: (1) how the politics of knowledge for peace has a direct impact on the kinds of policies which are thinkable and therefore implementable and (2) how our understanding (and presumption) of the research-policy-practice nexus is vital for understanding the politics of knowledge.

In doing so we speak to some well-known debates: the tension between international norms of transitional justice 'versus' local priorities and prefer- 
ences (Sharp, 2014); the extractive research practices of Global North research projects which seek to know and analyse Global South experiences (Ní Aoláin, 2015; Fletcher and Weinstein, 2018a, 2018b); and how knowledge is aligned with power and interests (Schotsmans, 2011; Macdonald, 2019). By unpacking the politics of knowledge we are not only seeking to peel away at the 'aura of naturalness and inevitability' (Sharp, 2018: 14) that surrounds transitional justice policy choices but we are also seeking to further a more nuanced understanding of politicization in the field, which has been highlighted by Lamont et al. (2019) as an important blind spot of the current scholarship. We also unpick and rethink the assumptions and frames underpinning our conceptions of knowledge, expertise, practice and policy-making. International norms do not only circulate in Global North universities, think tanks or donors; Global South scholars, practitioners and policy-makers also operate in problematic systems of power; expertise is not only to be found in the usual suspects but may emerge from local and regional priorities. We also see ways in which the different politics of knowledge are continually changing in response to changes in context and external factors but also through contestation and resistance from varied actors, both those in seemingly powerful and those in marginalized positions. The field of transitional justice derives its identity from its inherent tensions: claims to universality are being made while intervening in particular contexts; normative goals co-exist with a call for reflexivity and critique; and a crystallized international norm reproduces and is reproduced by an elite intervening in contexts of injustice and inequality. Seeking to understand the politics of knowledge which sustain these tensions is one of many possible and necessary steps towards resolving them.

The empirical chapters in this book have provided numerous examples of which policies are thinkable and which are not, based on the politics of producing, dissemination, negotiating, authorizing and legitimizing knowledge in each of the contexts that have been discussed. The cases of both Zimbabwe and Burundi have indicated that while consultations are considered as sites and instances of knowledge production, they merely serve to reaffirm pre-existing policy preferences. Consultations then merely serve to legitimate international policy choices which are based on narrowly defined goals and grounded in the normative frameworks derived from the UN four pillars approach. The case of South Sudan has shown, in contrast, that while local civil society and experts are demanding accountability and criminal justice, this becomes an unthinkable option in practice (if not on paper), due not only to the fact that the political elites who ought to be held accountable remain in power, but also because of the regional interests that drive political decision-making regarding the future of South Sudan. The knowledge which is available - on the causes and complexities of the conflict, on the population's preferences in terms of transitional justice, and on the application of transitional justice mechanisms 
such as (hybrid) courts in non-transition contexts - while certainly incomplete, remains ignored or is being withheld in accordance with specific agendas.

All of the cases presented in this book leave one policy choice unchallenged: that there should be transitional justice at all, that this is a discourse, a set of ideas and practices that can and should come to shape countries in transition. Even if not made explicit, all the authors and all the actors discussed in the various chapters assume and agree that transitional justice should, in one way or another, be applied to help countries in their (presumed) transitions. None of the cases presented opens up or even hints at the possibility of not doing transitional justice. This in itself shows not only the power of the discourse but also the norms that the field of transitional justice, as practice and an academic field of enquiry, has brought forth. It also shows the ultimate parameter within which the politics of producing knowledge in, on and for transitional justice currently operate: that transitional justice will come to shape any given context that considers itself or is being considered as being in transition. The question merely is which aspects of the transitional justice universe of options will be most prominent. This is where the politics of knowledge production currently play out and have the opportunity to shape our choices.

\section{NOTES}

1. Alex Boraine, former Vice-Chairperson of the South African Truth and Reconciliation Commission, at the opening of the Australian Reconciliation Convention in Melbourne in 1997, referenced in Menzies and McNamara (2008).

2. See https://www.ictj.org/about (accessed 7 April 2020).

3. See https://www.ictj.org/research (accessed 7 April 2020).

4. See https://www.ictj.org/research (accessed 7 April 2020).

5. For other examples see e.g. Schotsmans (2011), Ainley (2017), Jamar (2017) and Macdonald (2019).

\section{REFERENCES}

Ainley, K. (2017), 'Evaluating the Evaluators: Transitional Justice and the Contest of Values', International Journal of Transitional Justice, 11 (3), 421-42.

Albon, M. (1995), 'Project on Justice in Times of Transition. Report of the Project's Inaugural Meeting', in N. J. Kritz (ed.), Transitional Justice: How Emerging Democracies Reckon with Former Regimes. Vol. 1 General Considerations, Washington, DC: United States Institute of Peace Press, pp. 42-54.

Ancelovici, M. and J. Jenson (2013), 'Standardization for Transnational Diffusion: The Case of Truth Commissions and Conditional Cash Transfers', International Political Sociology, 7 (3), 294-312.

Arthur, P. (2009), 'How “Transitions” Reshaped Human Rights: A Conceptual History of Transitional Justice', Human Rights Quarterly, 31 (2), 321-67.

Arthur, P. (2018), 'Why Do Donors Choose to Fund Transitional Justice?', in C. Yakinthou and P. Arthur (eds), Transitional Justice, International Assistance, 
and Civil Society: Missed Connections, Cambridge: Cambridge University Press, pp. 209-41.

Arthur, P. and C. Yakinthou (2018), 'Changing Contexts of International Assistance to Transitional Justice', in C. Yakinthou and P. Arthur (eds), Transitional Justice, International Assistance, and Civil Society: Missed Connections, Cambridge: Cambridge University Press, pp. 1-24.

Berling, T. V. and C. Bueger (2016), Security Expertise: Practice, Power, Responsibility, Abingdon and New York: Routledge.

Bilgin, P. (2019), 'Worlding Conflict Resolution and Mediation Expertise: In the "Global South", in A. Leander and O. Wæver (eds), Assembling Exclusive Expertise: Knowledge, Ignorance and Conflict Resolution in the Global South, Abingdon: Routledge, pp. 77-93.

Bliesemann de Guevara, B. and X. Kurowska (2020), 'Building on Ruins or Patching up the Possible? Reinscribing Fieldwork Failure in IR as a Productive Rupture', in K. Kušić and J. Záhora (eds), Fieldwork as Failure: Living and Knowing in the Field of International Relations, Bristol: E-International Relations, pp. 163-74.

Boswell, C. (2008), 'The Political Functions of Expert Knowledge: Knowledge and Legitimation in European Union Immigration Policy', Journal of European Public Policy, 15 (4), 471-88.

Boswell, C. (2017), 'The Role of Expert Knowledge in International Organizations', in A. Littoz-Monnet (ed.), The Politics of Expertise in International Organizations: How International Bureaucracies Produce and Mobilize Knowledge, London and New York: Routledge, pp. 19-36.

Bush, K. and C. Duggan (2014), 'How Can Research Contribute to Peacebuilding?', Peacebuilding, 2 (3), 303-21.

Carr, E. S. (2010), 'Enactments of Expertise', Annual Review of Anthropology, 39 (1), $17-32$.

Colvin, C. J. (2008), 'Purity and Planning: Shared Logics of Transitional Justice and Development', International Journal of Transitional Justice, 2 (3), 412-25.

de Greiff, P. (2013), 'Transitional Justice Gets its Own Encyclopedia: Vitamins or Steroids for a Developing Field?', International Journal of Transitional Justice, 7 (3), 547-53.

Elster, J. (2013), 'Transitional Justice as Universal Narrative', in L. Israël and G. Mouralis (eds), Dealing with Wars and Dictatorships: Legal Concepts and Categories in Action, The Hague: T. M. C. Asser Press, pp. 77-81.

Evans, R. (2016), 'What Is Expertise? Technical Knowledge and Political Judgement', in T. V. Berling and C. Bueger (eds), Security Expertise: Practice, Power, Responsibility, Abingdon and New York: Routledge, pp. 19-36.

Fletcher, L. E. and H. M. Weinstein (2015), 'Writing Transitional Justice: An Empirical Evaluation of Transitional Justice Scholarship in Academic Journals', International Journal of Transitional Justice, 7 (2), 177-98.

Fletcher, L. E. and H. M. Weinstein (2018a), "North-South" Dialogue: Bridging the Gap in Transitional Justice: Workshop Transcript', Berkeley Journal of International Law, 37 (1), 218-333.

Fletcher, L. E. and H. M. Weinstein (2018b), 'How Power Dynamics Influence the "North-South" Gap in Transitional Justice', Berkeley Journal of International Law, 37 (1), 1-28.

Forsythe, D. P. (2011), 'Forum: Transitional Justice: The Quest for Theory to Inform Policy', International Studies Review, 13 (3), 554-78. 
Franzki, H. and M. C. Olarte (2014), 'Understanding the Political Economy of Transitional Justice: A Critical Theory Perspective', in S. Buckley-Zistel, T. Koloma Beck, C. Braun and F. Mieth (eds), Transitional Justice Theories, Abingdon: Routledge, pp. 201-21.

Glasius, M. (2002), 'Expertise in the Cause of Justice: Global Civil Society Influence on the Statute for an International Criminal Court', in H. K. Anheier, M. Glasius and M. Kaldor (eds), Global Civil Society Yearbook 2002, Oxford: Oxford University Press, pp. 137-68.

Grundmann, R. and N. Stehr (2012), The Power of Scientific Knowledge: From Research to Public Policy, Cambridge: Cambridge University Press.

Harris, V. (2014), 'Antonyms of Our Remembering', Archival Science, 14 (3-4), 215-29.

Jamar, A. (2014), 'Training in Transitional Justice in Rwanda and Burundi: International Aid for Whose Sake?', in F. Reyntjens, S. Vandeginste and M. Verpoorten (eds), L'afrique Des Grands Lacs, Annuaire 2013-2014, Paris: L'Harmattan, pp. 507-30.

Jamar, A. (2017), 'The Social Life of Policy Reports: Reporting as a Tool in the Transitional Justice Battlefield in Rwanda', Revue Internationale des Études du Développement, 232, 165-94.

Kagoro, B. (2012), 'The Paradox of Alien Knowledge, Narrative and Praxis: Transitional Justice and the Politics of Agenda Setting in Africa', in M. C. Okello, C. Dolan, U. Whande, N. Mncwabe, L.Onegi and S. Oola (eds), Where Law Meets Reality: Forging African Transitional Justice, Cape Town, Dakar, Nairobi and Oxford: Pambazuka Press, pp. 4-52.

Kritz, N. J. (1995), Transitional Justice: How Emerging Democracies Reckon with Former Regimes: Vol. 3 Laws, Rulings and Reports, Washington, DC: United States Institute of Peace Press.

Kritz, N. J. (2009), 'Policy Implications of Empirical Research on Transitional Justice', in H. van der Merwe, V. Baxter and A. R. Chapman (eds), Assessing the Impact of Transitional Justice: Challenges for Empirical Research, Washington, DC: United States Institute of Peace, pp. 13-22.

Lamont, C. K., J. R. Quinn and E. Wiebelhaus-Brahm (2019), 'The Ministerialization of Transitional Justice', Human Rights Review, 20 (1), 103-22.

Leander, A. and O. Wæver (2019), Assembling Exclusive Expertise: Knowledge, Ignorance and Conflict Resolution in the Global South, Abingdon: Routledge.

Lefranc, S. and F. Vairel (2013), 'The Emergence of Transitional Justice as a Professional International Practice', in L. Israël and G. Mouralis (eds), Dealing with Wars and Dictatorships: Legal Concepts and Categories in Action, The Hague: T. M. C. Asser Press, pp. 235-52.

Littoz-Monnet, A. (2017a), The Politics of Expertise in International Organizations: How International Bureaucracies Produce and Mobilize Knowledge, London and New York: Routledge.

Littoz-Monnet, A. (2017b), 'Expert Knowledge as a Strategic Resource: International Bureaucrats and the Shaping of Bioethical Standards', International Studies Quarterly, 61 (3), 584-95.

Macdonald, A. (2019), "Somehow This Whole Process Became So Artificial": Exploring the Transitional Justice Implementation Gap in Uganda', International Journal of Transitional Justice, 13 (2), 225-48.

McAuliffe, P. (2017), Transformative Transnational Justice and the Malleability of Post-Conflict States, Cheltenham, UK and Northampton, MA, USA: Edward Elgar Publishing. 
Menzies, K. and L. McNamara (2008), 'Towards Healing. Recognizing the Trauma Surrounding Aboriginal Family Violence', in B. Fawcett and F. Waugh (eds), Addressing Violence, Abuse, and Oppression. Debates and Challenges, London: Routledge, pp. 38-53.

Mourlon, F. (2016), 'Transposition and Adaptation of Models in Post-Conflict Northern Ireland: The Personal Experience of Brandon Hamber', Itineraires, 2.

Ní Aoláin, F. (2015), 'Southern Voices in Transitional Justice: A Critical Reflection on Human Rights and Transition', in U. Baxi, C. McCrudden and A. Paliwala (eds), Law's Ethical, Global and Theoretical Contexts: Essays in Honour of William Twining, Cambridge: Cambridge University Press, pp. 73-89.

Palmer, N., B. Jones and J. Viebach (2015), 'Introduction: Ways of Knowing Atrocity: A Methodological Enquiry into the Formulation, Implementation, and Assessment of Transitional Justice', Canadian Journal of Law and Society/Revue Canadienne Droit et Société, 30 (2), 173-82.

Poets, D. (2020), 'Failing in the Reflexive and Collaborative Turns: Empire, Colonialism, Gender and the Impossibilities of North-South Collaborations', in K. Kušić and J. Záhora (eds), Fieldwork as Failure: Living and Knowing in the Field of International Relations, Bristol: E-International Relations, pp. 102-15.

Quinn, J. R. (2016), 'The Development of Transitional Justice', in D. Jacobs (ed.), Research Handbook on Transitional Justice, Cheltenham, UK and Northampton, MA, USA: Edward Elgar Publishing, pp. 11-33.

Robins, S. and E. Wilson (2015), 'Participatory Methodologies with Victims: An Emancipatory Approach to Transitional Justice Research', Canadian Journal of Law and Society/Revue Canadienne Droit et Société, 30 (2), 219-36.

Schotsmans, M. (2011), “But We Also Support Monitoring”: INGO Monitoring and Donor Support to Gacaca Justice in Rwanda', International Journal of Transitional Justice, 5 (3), 390-411.

Sharp, D. N. (2014), 'Addressing Dilemmas of the Global and the Local in Transitional Justice', Emory International Law Review, 29 (1), 71-117.

Sharp, D. N. (2018), Rethinking Transitional Justice for the Twenty-First Century: Beyond the End of History, New York: Cambridge University Press.

Sitze, A. (2013), The Impossible Machine, Ann Arbor: University of Michigan Press.

Subotić, J. (2012), 'The Transformation of International Transitional Justice Advocacy', International Journal of Transitional Justice, 6 (1), 106-25.

Teitel, R. G. (2003a), 'Transitional Justice Genealogy', Harvard Human Rights Journal, 16, 69-94.

Teitel, R. G. (2003b), 'Transitional Justice in a New Era', Fordham International Law Journal, 26, 893-906.

Triponel, A. and S. Pearson (2010), 'What Do You Think Should Happen? Public Participation in Transitional Justice', Peace International Law Review, 22, 103-44.

van der Merwe, H. (2018), 'Conclusion: The Role of Local Civil Society in Shaping Transitional Justice in Africa', in J. Brankovic and H. van der Merwe (eds), Advocating Transitional Justice in Africa: The Role of Civil Society, Cham: Springer International Publishing, pp. 205-26.

van der Merwe, H. and M. Brinton Lykes (2018), 'Idealists, Opportunists and Activists: Who Drives Transitional Justice?', International Journal of Transitional Justice, 12 (3), 381-5.

Vanantwerpen, J. (2009), 'Moral Globalization and Discoursive Struggle: Reconciliation, Transitional Justice and Cosmopolitan Discourse', in D. C. Hammack 
and S. Heydemann (eds), Globalization, Philanthropy, and Civil Society: Projecting Institutional Logics Abroad, Bloomington: Indiana University Press, pp. 95-135.

Vinck, P. and P. Pham (2008), 'Ownership and Participation in Transitional Justice Mechanisms: A Sustainable Human Development Perspective from Eastern DRC', International Journal of Transitional Justice, 2 (3), 398-411.

Zunino, M. (2019), Justice Framed: A Genealogy of Transitional Justice, Cambridge and New York: Cambridge University Press.

Zvobgo, K. (2020), 'Demanding Truth: The Global Transitional Justice Network and the Creation of Truth Commissions', International Studies Quarterly, 64 (3), $609-625$. 